\title{
The administrative costs of taxation and customs clearing in Croatia, 1999-2001
}

Bratić, Vjekoslav; Bronić, Mihaela

Source / Izvornik: Occasional Paper Series, 2004, 8, 1 - 26

Journal article, Published version

Rad u časopisu, Objavljena verzija rada (izdavačev PDF)

https://doi.org/10.3326/ops.24

Permanent link / Trajna poveznica: https:/urn.nsk.hr/urn:nbn:hr:242:978008

Rights / Prava: Attribution-NonCommercial-NoDerivatives 4.0 International/ImenovanjeNekomercijalno-Bez prerada 4.0 međunarodna

Download date / Datum preuzimanja: 2023-04-26

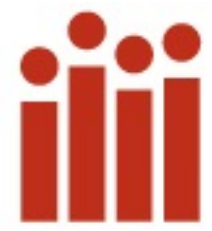

Institute of Public Finance Repository

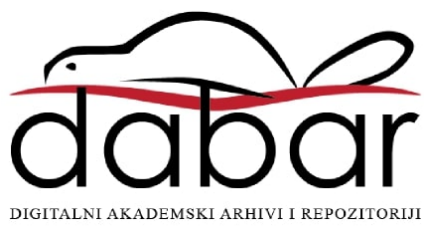




\title{
THE ADMINISTRATIVE COSTS OF TAXATION AND CUSTOMS CLEARING IN CROATIA, 1999-2001
}

\author{
Vjekoslav Bratić \\ Mihaela Bronić
}

Occasional Paper No. 24

November 2004 


\title{
THE ADMINISTRATIVE COSTS OF TAXATION AND CUSTOMS CLEARING IN CROATIA, 1999-2001 ${ }^{1}$
}

\author{
Vjekoslav Bratić \\ Institute of Public Finance, Zagreb \\ vieko@ijf.hr \\ Mihaela Bronić \\ Institute of Public Finance, Zagreb \\ $\underline{\text { mihaela@ijf.hr }}$
}

\begin{abstract}
In this article we have endeavoured to show the amount of the administrative costs of taxation and customs clearing in the Republic of Croatia in the last few years, to point out certain problems that exist in the functioning of the departments that collect them and to give some recommendations about how to reduce these problems. Particular attention is devoted to the Tax and Customs Administrations and to the Financial Police (as it was until disbanded). These departments have the task of collecting tax and customs revenues in line with the law, providing citizens with services from their domains that are as good as possible and paying attention to the costs that are incurred while they are carrying out their jobs, both the administrative costs (borne by the tax and customs authorities) and the compliance costs (borne by the taxpayers). In this paper too we have shown that many of the problems that showed up during the first investigation still exist, that is, that nothing has been done for these problems to be eliminated.
\end{abstract}

JEL Classification: G38

Key words: taxes and customs, tax administration, administrative costs of taxation and customs clearing, Croatia

\footnotetext{
${ }^{1}$ This research is a continuation of the investigation of 2000 by Ott and Bajo: Costs of Taxation in Transitional Countries: the Croatian Experience, Financijska teorija praksa 24 (2), 2000, pp.169-188.

The authors would like to thank Oskar Cukrov from Customs Administration for valuable comments and contributions.

This research was supported by a grant from the CERGE-EI Foundation under a program of the Global Development Network. Additional funds for grantees in the Balkan countries have been provided by the Austrian Government through WIIW, Vienna. All opinions expressed are those of the author(s) and have not been endorsed by CERGE-EI, WIIW, or the GDN". Additional funds were also provided by the Institute of Public Finance Zagreb, Croatia the institution that have conduced the project «Administrative and Compliance Costs of Taxation in Croatia». This paper is part of that project.

This article is published in Croatian in the journal "Financijska teorija i praksa", 28(3), 2004, pp. 377-401 and is downloadable from: http://www.ijf.hr/financijska_praksa/PDF-2004/3-04/bratic-pitarevic.pdf.
} 


\section{INTRODUCTION}

Every job and work that is done costs something and involves a price. Hence collecting taxes too has a price. The assignment of collecting taxes and customs in Croatia belongs to the Tax and Customs administration, and belonged to the Financial Police as well until it was abolished. They incur costs during their work. The costs of collecting taxes consist of the administrative costs of given departments and the costs of the taxpayer (which we shall ignore in this paper). For a given department to be as effective as possible, it needs a certain degree of independence, both in finances and in organisation. Efficiency inheres in the collection of as large amounts of customs duties and taxes as possible with as few costs as possible. But independence in and of itself is not enough; rather, what is needed is expertise and knowledge from the employees of these administrations. Since becoming independent, Croatia has been working, with greater or lesser success, on the establishment of just such departments. The purpose of this paper is to show the amount of the administrative costs and the efficiency of these departments in the collection of financial resources, and also to point out any failures there might be and any opportunities for improvement of the entire system. In the first part of the work the emphasis will be on the definition and compass of administrative costs and on the basic problems of the research. The central part is devoted to an analysis of the three departments charged with the collection of public revenue, while the last part deals with amounts, total administrative costs and their financial effects.

\section{ANALYSIS AND INVESTIGATION OF ADMINISTRATIVE COSTS-YES OR NO?}

In the previous investigation concerning the administrative costs of taxation in the Republic of Croatia, Ott and Bajo gave an answer to the question about why one should measure the costs of collecting taxation in Croatia. Among other things, the need to analyse the costs of tax collection, that is, to analyse administrative costs, derives from several facts. The first fact is that the administrative costs of some country reduce its export competitiveness for they are an important part of the total costs in the economy and as such constitute an additional tax burden on products and services. The second factor can be seen in the fact that the lower the costs of gathering taxes, the simpler the taxation system. The third fact says that the administrative costs / compliance costs ratio should be able to show which of these costs is too large and where in some redistribution savings might be made ${ }^{2}$. This ratio is also important because, for example, the failure to provide free information ${ }^{3}$ about tax changes by the tax administration or the reduction of such provisions results in public sector costs (administrative sector costs) being transferred to the private sector (compliance costs) ${ }^{4}$. The fourth fact is that the efficiency of a tax administration is measured by tax evasion ${ }^{5}$, that is, that a maximally efficient tax administration

\footnotetext{
${ }^{2}$ Sandford (1989, p. 203) and Allers (1994, p. 42) say that it is better to have more administrative costs and as few compliance costs as possible, except in an exceptional case, or when it can be shown that the private sector might perform it more effectively.

${ }^{3}$ It is praiseworthy that since 2002 brochures have been published and given out by the Institute for Public Finances about various forms of taxes, liabilities and rights of taxpayers and so on, all of them one form of free information. The Institute has also a booklet about the Croatian tax system.

${ }^{4}$ See Allers, p. 41.

${ }^{5}$ Detailed data and estimates about tax evasion in Croatia can be seen Madžarević-Šujster (2002).
} 
exists when tax evasion does not exist (potential tax revenue is the same as the real tax revenue and there is no tax gap) ${ }^{6}$.

\section{WHAT DO ADMINISTRATIVE COSTS CONSIST OF?}

It is a generally accepted rule, which has been confirmed in practice countless times, that there can be no good tax policy without a good tax administration. A tax administration in which inadequately educated, uninterested and slack officials work, with widespread corruption, has a crucially negative effect on the realisation of the tax policy. In an evaluation of the effectiveness of a tax administration we have to take into account the costs of assessing taxes, and also the costs of collecting and checking the collection of taxes. Here it is necessary to pay attention to both the costs that tax administration has during the performance of its work and the costs that the individual taxpayer has while meeting its tax liabilities.

Speaking thus of the costs of a tax system, Sandford, Godwin and Hardwick (1989) distinguish administrative costs (public sector costs) and compliance costs (the costs of the taxpayer). The subject of this paper is the administrative costs of taxation. All though all the authors quoted mention that sometimes it is not clear what the administrative costs of taxation are, they advocate the following definition. The administrative costs of taxation are those costs of the public sector that are incurred during the administration of the existing tax laws. Thus we can define them as the costs of implementing the existing tax laws, including any proposals for changes in them. ${ }^{7}$

According to the classification employed in the national Budget, this contains operating expenses (for employees, material used, energy, computers, telecommunications and postal services, utility and other services for regular requirements and current maintenance), financial and other expenditure (financial expenditure and other unspecified expenditures) and expenditure for the procurement, construction and investment maintenance of fixed assets). Administrative costs include the costs of the Tax Administration, the Financial Police and the Customs Administration. These departments (the Financial Police only up to its abolition in June 2001) are charged with the collection of tax revenue and customs duties.

All the expenditures of these units are mostly financed out of the national Budget, and are to a smaller extent financed out of their own resources. The aggregate of budgetary resources and own resources provides us a complete picture of the total administrative costs for these organisational units.

Apart from the costs of these three departments arising out of the regular activities of the bodies charged with collecting public revenue, one should also consider the costs of the departments that indirectly collect taxes and customs duties (in Croatia, the Payments Clearing Institute, ZAP, now known as FINA), as well as the costs of the courts that deal with given tax and customs cases.

\footnotetext{
${ }_{7}^{6}$ See Allers, pp. 24-26.

${ }^{7}$ A similar definition of administrative costs is provided by Allers (1994) who defines administrative costs as those that on the whole arise in the public sector institutions during the administration of the tax system. He also states that the costs which have arisen in the public sector institutions during the taxation of taxpayers by deduction should be considered compliance costs (costs of the taxpayer) and not administrative costs.
} 
The attention of this paper is fastened on the administrative costs directly connected with the collection of tax revenue and customs duties, that is, the costs of the Tax and Customs Administration, and the Financial Police.

\section{FUNDAMENTAL PROBLEMS OF RESEARCH}

As in the previous paper, in this article too there are still the problems of monitoring and comparing data from different sources, and problems and dubieties about obtaining a total picture and estimate of total administrative costs.

The Financial Police (FP). Data about the total balance sheet of revenue and expenditure of the FP are still secret. Some of the FP's own revenue is not stated in the Budget. After the abolition of the FP it is not clear whom we can turn to in order to obtain details about the operations of the FP. Also unknown is any information about where the former employees of the FP who were supposed to be transferred to various sections of the Tax Administration, the Customs Administration and the Finance Ministry actually ended up.

The Customs Administration (CA). The CA has separate accounts for given purposes to which resources for incentives and other needs for employees (training, team-building and so on) are directed. A positive step in this research is that we have been able to obtain data about the CA's own resources, which in the earlier case was not possible.

Analysis of the effectiveness of the courts in the procedure of determining and collecting public revenue. The prior research drew attention to the following circumstances related to this problem area. In the Republic of Croatia there are no systematic records about the number of cases settled that result in the compulsory collection of public revenue. The number of cases about the collection of public revenue settled is not a reliable indicator of the effectiveness of the courts. The analysis must have factored into it the total amounts of public revenue collected. For example, if some court settles $70 \%$ of its cases, it does not necessary mean that it is effective in its work because in those unsettled $30 \%$ of cases there might be $60 \%$ of the amounts that have to be collected in the year under observation. Consequently, the mere number of cases settled in a court does not have to be any indication of its effectiveness, because there are differences in the monetary resources collected by compulsory collection, and these are after all a more important factor of the efficacy of the courts in this case.

Quite often a court procedure will drag on for a long time, and it may happen that some item of public revenue will remain uncollected for a longer period.

In addition, there are no systematic figures about the number of tax amnesties in Croatia, or the amounts of them.

Financial police and the courts. According to court rulings from the current year, and in line with judicial decisions regarding cases from previous years, until the abolition of it, the FP carried out the forcible collection of taxes and other public revenue (contributions for retirement and health insurance). Who took over this part of the work of the FP after its abolition is not clear. It is also not known how much revenue was collected by compulsory means. 
The administrative costs of the extra-budgetary funds that relate to the collection of contributions. Theoretically, in order to obtain a complete picture of the administrative costs of taxation and customs clearing the administrative costs of the extra-budgetary funds ${ }^{8}$ (the retirement and health insurance funds, and some others) should be included as well, but we were not able to arrive at these figures. The FP was charged with the compulsory collection of taxes and contributions. Taxes were transferred directly to the budget, while contributions for social security were transferred to the extra-budgetary funds. What happened after the abolition of the FP is hard to say. For these reasons it has been impossible to calculate the administrative costs of contributions, and so we did the research without them. By the time of the next investigation it should be possible to see the ways in which such figures can be obtained.

Payments clearing reform and its impact on the administrative costs of taxation and customs clearing. As a result of the payments clearing reforms in which ZAP was done away with, FINA was created as the legal successor to this institution. The Payments Clearing Law transferred the authority for payments clearing to the banks, which have partially taken this over for large clients. But some have remained with FINA, because of the necessary infrastructure, which it has; alternatively, FINA still works for some of the banks. It is a question what amounts of administrative costs will now be incurred by the banks and what by FINA, and whether this means that the part of payments clearing that went to the banks will be transferred by the banks to the tax payers (at the moment, a commission of 50 lipa per order for the payment of tax is paid to the banks or to ZAP, i.e., FINA). All this will of course have an effect on the amount of the administrative costs of taxation, and the next research project should attempt to arrive at these figures too.

\section{THE COSTS OF THE TAX ADMINISTRATION 1999-2001}

The work, organisation, affairs and manner of work of the Tax Administration, qua independent and single administration that is part of the Ministry of Finance, are regulated by the Tax Administration Law (Official Gazette, 75/93). According to Article 3 of this Law, the TA undertakes such tasks as the organisation and coordination, monitoring and control of the collection of budgetary revenue; the collection, recording and processing of data important for assessing and paying taxes, fees and other budgetary revenue; determination of the tax liabilities of legal and natural entities; control of taxpayers for the sake of determining that they have calculated and executed their tax liabilities promptly and properly; the determination of infringements of the tax laws and handling offence procedures; recording and processing data about calculated and collected taxes; monitoring and analysing the application of tax regulations and tax systems; the forcible collection of taxes, fees and other budgetary revenue, and the collection and automatic processing of data about budgetary revenue via a single information system.

This law also prescribes the matters that are to be carried out by the regional offices and local offices of the Tax Administration.

\footnotetext{
${ }^{8}$ See Allers (1998) for the way he has done this for the Netherlands.
} 
The work of the Tax Administration is public, and data about tax bases, about assessed, paid and unpaid tax, in the amount reported by the taxpayer, or that have been determined in the assessment and control of the calculation and payment of taxes procedure, are also public. Other data that an official person of the Tax Administration finds out about the work and activities of a given taxpayer during the process of control and assessment are official secrets.

\section{The Tax Administration's own resources}

The Tax Administration is partially financed, alongside resources from the national Budget, out of its own resources that are created as a consequence of collecting local taxes. According to the data of the central office of the Tax Administration, own resources were created as follows: in 1999, 95.3 million kuna; in 2000, 115 million kuna; and in 2001, 72 million kuna.

\section{Figures concerning the expenditure of the Tax Administration}

At the levels of individual offices of the Tax Administration, records about the revenue and expenditure of the Tax Administration are kept. But total control and centralisation of the work of the Tax Administration is under the control of the Central Office, which monitors and keeps accounting and records systems for revenue and expenditure.

\section{Administrative costs of the Tax Administration}

As pointed out in the previous investigation, the costs of the Tax Administration are not monitored according to kinds of tax, rather according to the account plan and some other methodology of calculation, and for this reason it is impossible to determine the costs of taxation for the taxpayer according to individual kinds of tax. For this reason, we will consider the administrative costs and their structure.

Table 1 Total expenditure of the TA (in million kuna)

\begin{tabular}{|l|r|r|r|r|r|r|r|r|r|r|}
\hline & 1997 & $\mathbf{\%}$ & $\mathbf{1 9 9 8}$ & $\mathbf{\%}$ & $\mathbf{1 9 9 9}$ & $\mathbf{\%}$ & $\mathbf{2 0 0 0}$ & $\mathbf{\%}$ & $\mathbf{2 0 0 1}$ & $\mathbf{\%}$ \\
\hline Financed from the budget & 273.8 & 70.0 & 334.7 & 72.0 & 423.6 & 81.8 & 383.3 & 76.9 & 358.6 & 83.3 \\
\hline $\begin{array}{l}\text { Financed from TA own } \\
\text { resources }\end{array}$ & 117.0 & 30.0 & 132.9 & 28.0 & 94.3 & 18.2 & 115.0 & 23.1 & 72.1 & 16.7 \\
\hline Total TA expenditure & $\mathbf{3 9 0 . 8}$ & $\mathbf{1 0 0 . 0}$ & $\mathbf{4 6 7 . 6}$ & $\mathbf{1 0 0 . 0}$ & $\mathbf{5 1 7 . 9}$ & $\mathbf{1 0 0 . 0}$ & $\mathbf{4 9 8 . 3}$ & $\mathbf{1 0 0 . 0}$ & $\mathbf{4 3 0 . 7}$ & $\mathbf{1 0 0 . 0}$ \\
\hline
\end{tabular}

Source: Reports of the Tax Administration from 1997 to 2001.

Unfortunately, TA data and data about the execution of the budget for individual years differ. Since the amounts however are not very diverse, the basic analysis has been carried out according to the data obtained from the Tax Administration.

The earlier research showed that for the period from 1995 to 1999 while about $70 \%$ of the expenditure of the TA was financed with budgetary resources, the remaining $30 \%$ financed from its own resources.

In the period from 1997 to 2001 , about $80 \%$ of the total expenditure of the TA was financed from the Budget, and the other $20 \%$ came from TA own resources. These figures indicate a rise in the proportion of financial resources from the budget, and a fall in the share of the TA's own resources. 
In the next table we look at the relation of total tax revenue and real administrative expenditure (the aggregate of budgetary resources and the TA's own resources) as indicator of the efficiency of the Tax Administration. This table shows the administrative costs of the TA per unit of collected taxes in million kuna for the period.

Table 2 Administrative costs of the TA per unit of collected tax (in million kuna)

\begin{tabular}{|l|r|r|r|r|r|}
\hline & $\mathbf{1 9 9 7}$ & $\mathbf{1 9 9 8}$ & $\mathbf{1 9 9 9}$ & $\mathbf{2 0 0 0}$ & $\mathbf{2 0 0 1}$ \\
\hline Real expenditures of the TA & 391 & 468 & 518 & 498 & 431 \\
\hline Tax revenue (not inc. contributions) & 31,338 & 40,327 & 38,318 & 39,939 & 39,999 \\
\hline (RE/TR)*100 (in \%) & 1.25 & 1.16 & 1.35 & 1.24 & 1.08 \\
\hline
\end{tabular}

Source: Reports of the Tax Administration from 1997 to 2001 and Report of the Finance Ministry (75/02).

According to these figures, total administrative costs came to about $1.18 \%$ of total tax revenue during the 1997-2001 period.

If we compare these figures with those obtained for the 1995 to 1999 period, we will notice that the ratio is more or less at the same level (in that period it came to about $1.17 \%$ ).

For one kuna of tax revenue collected, in recent years the TA has been spending increasingly little money, although the level is more or less always the same. Thus during 2001 about 1 lipa was spent. These data lead to the conclusion that the TA is increasingly professional and effective in its work.

In the following tables we shall show only the structure of the total expenditure of the TA during this period and the structure of individual items of expenditure executed in the highest amounts.

Table 3a Structure of total TA expenditure (in million kuna)

\begin{tabular}{|l|r|r|r|r|r|r|r|r|r|r|}
\hline Structure & $\mathbf{1 9 9 7}$ & $\mathbf{1 9}$ & $\mathbf{1 9 9 8}$ & $\mathbf{\%}$ & $\mathbf{1 9 9 9}$ & $\mathbf{\%}$ & $\mathbf{2 0 0 0}$ & $\mathbf{\%}$ & $\mathbf{2 0 0 1}$ & $\mathbf{\%}$ \\
\hline $\begin{array}{l}\text { Operating expenditure (wages. } \\
\text { material, current maintenance) }\end{array}$ & 282.5 & 72.3 & 364.6 & 78.0 & $\mathbf{4} 41.9$ & 85.4 & 424.5 & 85.2 & 371.7 & 86.3 \\
\hline $\begin{array}{l}\text { Current external expenditure } \\
\text { for materials and services } \\
\text { (financial and other) }\end{array}$ & 27.5 & 7.0 & 23.9 & 5.1 & 17.5 & 3.4 & 15.9 & 3.2 & 15.6 & 3.6 \\
\hline Procurement of fixed assets & 80.8 & 20.7 & 79.1 & 16.9 & 58.4 & 11.2 & 57.9 & 11.6 & 43.4 & 10.1 \\
\hline Total & $\mathbf{3 9 0 . 8}$ & $\mathbf{1 0 0 . 0}$ & $\mathbf{4 6 7 . 6}$ & $\mathbf{1 0 0 . 0}$ & $\mathbf{5 1 7 . 8}$ & $\mathbf{1 0 0 . 0}$ & $\mathbf{4 9 8 . \mathbf { 3 } ^ { \mathbf { 9 } }}$ & $\mathbf{1 0 0 . 0}$ & $\mathbf{4 3 0 . 7}$ & $\mathbf{1 0 0 . 0}$ \\
\hline
\end{tabular}

Source: Reports of the Tax Administration from 1997 to 2001.

According to Table 3a the greatest amounts are earmarked for operational expenses, which include staff expenditures and current expenditure for material and services. In the whole of this period, this expenditure made up about $85.5 \%$ of the total expenditure of the TA.

The same expenditures for the period from 1995 to 1999 came on average to about $75 \%$. We can see then that in this period, for these expenditures alone, there was an increase of about $10 \%$.

Similarly, though, a fall in the proportion of current external outgoings for materials and services (from $6.5 \%$ in the previous observation period to about $3.4 \%$ in this period) and a fall in the proportion of capital expenditure (from $18 \%$ in the previous period observed to about $11.2 \%$ in this period) can be observed.

\footnotetext{
${ }^{9}$ The TA includes in real costs inland loans made in excess of 5.8 million kuna, and according to their data, the total real costs for 2000, for example, would come to 504 million kuna. For this analysis we have used real costs without inland loans made.
} 
The following table shows us the items that accounted for the greatest proportions of the total expenditure.

Table $3 b$ Structure of individual items of the major TA expenditures (in million kuna)

\begin{tabular}{|l|r|r|r|r|r|r|r|r|r|r|}
\hline & $\mathbf{1 9 9 7}$ & $\mathbf{\%}$ & $\mathbf{1 9 9 8}$ & $\mathbf{\%}$ & $\mathbf{1 9 9 9}$ & $\mathbf{\%}$ & $\mathbf{2 0 0 0}$ & $\mathbf{\%}$ & $\mathbf{2 0 0 1}$ & $\mathbf{\%}$ \\
\hline Staff expenditure* & 204.4 & 57.6 & 268.0 & 62.1 & 328.3 & 65.6 & 324.5 & 68.6 & 275.5 & 68.3 \\
\hline $\begin{array}{l}\text { Current expenditure for } \\
\text { materials and services } \\
\text { (financial and other) }\end{array}$ & 69.5 & 19.6 & 84.6 & 19.6 & 113.6 & 22.7 & 90.4 & 19.1 & 84.4 & 20.9 \\
\hline Procurement of fixed assets & 80.8 & 22.8 & 79.1 & 18.3 & 58.3 & 11.7 & 57.9 & 12.3 & 43.4 & 10.8 \\
\hline Total & $\mathbf{3 5 4 . 7}$ & $\mathbf{1 0 0 . 0}$ & $\mathbf{4 3 1 . 7}$ & $\mathbf{1 0 0 . 0}$ & $\mathbf{5 0 0 . 2}$ & $\mathbf{1 0 0 . 0}$ & $\mathbf{4 7 2 . 8}$ & $\mathbf{1 0 0 . 0}$ & $\mathbf{4 0 3 . 3}$ & $\mathbf{1 0 0 . 0}$ \\
\hline
\end{tabular}

Source: Reports of the Tax Administration, 1997-2001.

* Gross salary and compensations, employer's contributions.

We can see that in the structure of expenditures, the dominant role is that of staff expenditure, i.e., outgoings for wages, contributions and reimbursement of employees' costs. On these alone is spent $64.4 \%$ of the major expenditure seen in this period, with a tendency to rise, from $57 \%$ to $68 \%$. Second most important is current expenditure for materials and services, which on average amounted to about $20.4 \%$ and is constant. The third category is capital expenditure, which on average made about $15.2 \%$ with a tendency to decline.

According to the total expenditure for staff and the number of employees in this period, the following table shows the share of expenditure per employee in the TA in kuna.

Table 4 Expenditure per employee in the TA

\begin{tabular}{|l|r|r|r|r|r|}
\hline & 1997 & $\mathbf{1 9 9 8}$ & $\mathbf{1 9 9 9}$ & $\mathbf{2 0 0 0}$ & $\mathbf{2 0 0 1}$ \\
\hline Staff expenditure* (in million kuna) $^{*}$ & 204,383 & 267,998 & 328,283 & 324,546 & 275,529 \\
\hline Average number of employees in the TA & 3,285 & 3,679 & 3,810 & 3,956 & 3,814 \\
\hline Expenditure per employee (in kuna) & 62,217 & 72,845 & 86,163 & 82,039 & 72,241 \\
\hline
\end{tabular}

Source: TA Reports, 1997-2001.

* Gross salary and compensations, employers' contributions.

In the 1999-2001 period a fall in the expenditure per employee from 86,000 in 1999 to 72,000 in 2001 was observed.

These figures are completely opposite to those for the period from 1995 to 1999 , when there was a tendency for expenditure per employee to rise (from 55,853 kuna in $1995^{10}$ to 72,845 kuna in 1998). In the whole of the period there was no very great inflation or change in the exchange rate ${ }^{11}$. A reduction in the number of employees during 2001 as against the 1999 level is also observed.

\section{FINANCIAL POLICE}

The work of the FP was regulated by the Financial Police Law. According to this law, the main assignment of the FP was to undertake all and any actions to increase discipline in the payment of liabilities within the framework of public revenue. In a broader sense, the work of the FP also covered

\footnotetext{
${ }_{11}^{10}$ See the previous research for the 1995-1998 period.

${ }^{11}$ Inflation came to $5 \%$ a year, while the exchange rate for the kuna and German mark was about 3.85 : 1 in the whole of the period under observation.
} 
the sanctioning of all irregularities related to certain offences determined in the performance of matters from the sphere of work, business offences and serious offences, as well as investigation of economic crimes.

As part of the reorganisation of the national administration, for the sake of the rationalisation of matters and assignments, in May 2001 the Financial Police was abolished.

The abolition of the FP was explained by the desire for as efficient a control of financial flows and economic crime as well, which the FP, in the opinion of the government, had not yet managed to do. The affairs of the FP needed to be taken over by a "reorganised and modernised" TA, the CA and reinforced business crime sections of the Internal Affairs Ministry. The authorities of these departments had anyway previously overlapped with the disbanded FP. Although the FP was founded before the passing of the Tax Administration Law and carried out some of the affairs of the TA, the FP was obliged to work together with the TA and with other organs of the national administration, bodies of local government and self-government units, and legal and natural entities were bound to provide the FP with data and let it see financial documents, business books and other documents necessary for control to be undertaken. The 700 or so employees of the $\mathrm{FP}^{12}$ were supposed to be reassigned to the tax, customs and police series. Whether this was all really done, we cannot say, because it is impossible to arrive at these data.

The FP carried out compulsory collection of taxes and contributions. The taxes were directly transferred into the Budget, while contributions were directed to the extra-budgetary funds (pensions and health insurance).

A special organisation was set up in the central FP department, the Internal Control Department, headed by the assistant chief inspector of the FP. The control took in the organisational structure and its functioning, the planning of work assignments and checks on whether the plan was being met, operational procedures and the execution of work assignments, work discipline, the material equippedness of FP stations and the disposal of financial and other resources.

\section{The Financial Police's own resources}

Up till the abolition of the FP in May 2001, $2 \%$ of the claims obtained according to FP rulings were transferred to the department. Of course, until it was abolished, the FP was financed mainly with resources of national Budget. Neither in this research nor in the previous investigation was it possible to arrive at data from the Financial Police itself about its total resources (its own and Budgetary resources). We still know only the amount that the FP obtained from the Budget. It was according to these data as well as data from the National Auditing Office that this analysis was made.

\section{Administrative costs of the Financial Police}

We shall analyse data about the execution of the Budget for the period from 1999 to 2001 . Only, to repeat, the budgetary part of the FP resources is analysed, while the FP's own resources are not analysed.

\footnotetext{
${ }^{12}$ Information taken from Vjesnik, 25 May 2001.
} 
Table 5a Structure of total FP expenditure according to the execution of the Budget (in million kuna)

\begin{tabular}{|l|r|r|r|r|r|r|r|r|r|r|}
\hline & $\mathbf{1 9 9 7}$ & $\mathbf{1 9 9 8}$ & $\mathbf{1 9}$ & $\mathbf{1 9 9 9}$ & $\mathbf{2 0 0 0}$ & $\mathbf{2 0 0 1}$ & $\mathbf{2 0}$ \\
\hline $\begin{array}{l}\text { Operational expenditure (for } \\
\text { staff, material and current } \\
\text { expenditures) }\end{array}$ & 75.3 & 96.9 & 88.1 & 95.1 & 107.9 & 89.3 & 87.1 & 98.1 & 69.8 & 98.4 \\
\hline $\begin{array}{l}\text { Current external expenditure for } \\
\text { materials and services (financial } \\
\text { and other) }\end{array}$ & 0.5 & 0.7 & 0.6 & 0.7 & 0.6 & 0.5 & 0.3 & 0.3 & 0.2 & 0.3 \\
\hline Procurement of fixed assets & 1.9 & 2.4 & 3.9 & 4.2 & 12.3 & 10.2 & 1.4 & 1.6 & 0.1 & 1.3 \\
\hline Total & $\mathbf{7 7 . 7}$ & $\mathbf{1 0 0 . 0}$ & $\mathbf{9 2 . 6}$ & $\mathbf{1 0 0 . 0}$ & $\mathbf{1 2 0 . 8}$ & $\mathbf{1 0 0 . 0}$ & $\mathbf{8 8 . 8}$ & $\mathbf{1 0 0 . 0}$ & $\mathbf{7 0 . 1}$ & $\mathbf{1 0 0 . 0}$ \\
\hline
\end{tabular}

Source: Report on the execution of the budget from 1997 to 2001.

Operating expenses (for staff, material and current maintenance) make up the bulk of the expenditure. On average they constituted about $95.6 \%$ of total expenditure. It is interesting that during 1999 there was a fall in such expenditures, but right in 2000 and 2001 they came back to the level of about $98.3 \%$. At the same time, there was a declining trend in expenditure for the procurement of fixed assets, from $10.2 \%$ in 1999 to $1.3 \%$ in 2001 . However, a considerable increase in such expenditure could be seen during 1999.

Table $5 b$ The structure of individual items of major FP expenditure (in million kuna)

\begin{tabular}{|l|r|r|r|r|r|r|r|r|r|r|}
\hline & $\mathbf{1 9 9 7}$ & $\mathbf{1 9 9 8}$ & $\mathbf{1 9}$ & $\mathbf{1 9 9 9}$ & $\mathbf{2 0 0 0}$ & $\mathbf{2 0 0 1}$ & $\mathbf{2 0}$ \\
\hline Staff expenditure $^{*}$ & 65.8 & 89.3 & $\mathbf{7 5 . 5}$ & 85.9 & 93.9 & 80.7 & 80.7 & 92.0 & 64.3 & 92.8 \\
\hline $\begin{array}{l}\text { Expenditure for materials, } \\
\text { power and utilities }\end{array}$ & 6.0 & 8.1 & 8.5 & 9.7 & 10.1 & 8.7 & 5.6 & 6.4 & 4.9 & 7.1 \\
\hline Procurement of fixed assets & 1.9 & 2.6 & 3.9 & 4.4 & 12.3 & 10.6 & 1.4 & 1.6 & 0.1 & 0.1 \\
\hline Total & $\mathbf{7 3 . 7}$ & $\mathbf{1 0 0 . 0}$ & $\mathbf{8 7 . 9}$ & $\mathbf{1 0 0 . 0}$ & $\mathbf{1 1 6 . 3}$ & $\mathbf{1 0 0 . 0}$ & $\mathbf{8 7 . 7}$ & $\mathbf{1 0 0 . 0}$ & $\mathbf{6 9 . 3}$ & $\mathbf{1 0 0 . 0}$ \\
\hline
\end{tabular}

Source: Report on Execution of the Budget from 1997 to 2001.

* Gross salary and compensations, employers' contributions.

In the structure of FP expenditure between 1997 and 2001, the greatest item was that of staff expenditures (salaries, subsistence expenditure and contributions). On average they account for about $88 \%$. Total expenditure in absolute amounts fell from 116 million kuna in 1999 to 69 million kuna in 2001. The most important change happened in the procurement of fixed assets, when in 1999 this came to 12.3 million kuna, which was a remarkable increase as against other years.

Table 6 Expenditure for employees in the FP

\begin{tabular}{|l|r|r|r|r|r|}
\hline & $\mathbf{1 9 9 7}$ & $\mathbf{1 9 9 8}$ & $\mathbf{1 9 9 9}$ & $\mathbf{2 0 0 0}$ & Up to June 2001 \\
\hline Staff expenditure* (in million kuna) & 65,833 & 75,550 & 93,915 & 80,651 & 64,339 \\
\hline Number of employees & 820 & 846 & 837 & 872 & ${\text { cca } 700^{* *}}^{*}$ \\
\hline Expenditure per employee in kuna & 80,284 & 89,303 & 112,204 & 92,490 & 91,912 \\
\hline
\end{tabular}

Source: Report on the Execution of the Budget from 1997 to 2001.

* Gross salary and compensations, employers' contributions.

**Vjesnik, 25 May 2001.

According to data about total expenditure for employees and the number of employees in the FP, we have endeavoured to show the dynamics of the movements in expenditure per employee in the period from 1997 to 2000 . We were not able to obtain the precise number of employees for 2001, that is, until the abolition of the FP. 
From 1997, employee expenditure was on the rise, and in 1999 reached 112,000 kuna per employee, and then in 2000 it fell. We cannot give accurate information concerning 2001.

\section{The efficiency of the Financial Police in collecting public revenue}

As in the previous research, it was very difficult, in fact almost impossible, to say precisely how much public revenue was collected by the work of the FP. For this reason it is difficult to show the basic indicators of the work and effectiveness of the FP, and of its administrative costs.

Table 7 Structure of defined public revenue (in million kuna)

\begin{tabular}{|l|r|r|r|r|r|r|r|r|}
\hline Defined public revenue & $\mathbf{1 9 9 7}$ & $\mathbf{\%}$ & $\mathbf{1 9 9 8}$ & $\mathbf{\%}$ & $\mathbf{1 9 9 9}$ & $\mathbf{\%}$ & $\mathbf{2 0 0 0 ^ { \mathbf { 1 3 } }}$ & $\mathbf{\%}$ \\
\hline Legal entities & 871.5 & 90.0 & 972.1 & 88.0 & $1,436.2$ & 91.0 & - & \\
\hline Financial institutions & 14.7 & 1.0 & 52.4 & 5.0 & 41.8 & 3.0 & - & \\
\hline Natural entities - tradesmen & 85.6 & 9.0 & 74.4 & 7.0 & 97.5 & 6.0 & - & \\
\hline Total & $\mathbf{9 7 1 . 8}$ & $\mathbf{1 0 0 . 0}$ & $\mathbf{1 , 0 9 8 . 9}$ & $\mathbf{1 0 0 . 0}$ & $\mathbf{1 , 5 7 5 . 5}$ & $\mathbf{1 0 0 . 0}$ & $\mathbf{2 , 4 0 7 . 8}$ & $\mathbf{1 0 0 . 0}$ \\
\hline
\end{tabular}

Source: FinPol (2000), paper of Financial Police of the Republic of Croatia, No. 33 and 34.

FinPol (2001), paper of Financial Police of the Republic of Croatia, No. 35.

Legal entities are public and private and major state-owned companies.

Financial institutions are banks, savings banks and insurance companies.

Public revenue is made up of VAT, income and corporate income tax, excise, contributions for pensions and social security, employment contributions and other public revenue (interest, fees).

In the structure of determined public revenue, data about total amounts are known only for 1999 and 2000, although even for the latter year they are not as complete as in 1999. We were unable to obtain any detailed data for 2000 and 2001.

In the whole of the period up to 1997 there is an upward trend in determined public revenue at an average level of up to $53 \%(1999 / 2000)$. It can be assumed that later too in the structure of public revenue that had to be obtained via compulsory collection it was mostly large taxpayers and legal entities that were involved (as can be seen from the data up to November 2000), then natural entities and, finally, financial institutions. But as we have already remarked, and as can also be seen from this table, although the data up to November 2000 confirm this trend, we do not have complete information concerning these figures.

As one of the indicators of efficiency we can also see the relation between collected and determined tax revenue (where there was a liability to pay, but the revenue was not collected). Here too there is a certain limitation because part of the revenue from the previous year can be collected only in the current year, which depends on court decisions, because the procedure for the compulsory collection of tax can be long-lasting. For these indicators, too, there are no data for 2001.

Table 8 Percentage of collection of public revenue in the FP (in million kuna)

\begin{tabular}{|l|r|r|r|r|r|}
\hline & $\mathbf{1 9 9 7}$ & $\mathbf{1 9 9 8}$ & $\mathbf{1 9 9 9}$ & $\mathbf{2 0 0 0}$ & Up to June 2001 \\
\hline Total determined public revenue (1) & 971.8 & $1,098.9$ & $1,575.5$ & $2,407.8$ & - \\
\hline Collected public revenue (2) & 422.8 & 469.5 & 805.4 & 578.3 & - \\
\hline
\end{tabular}

\footnotetext{
${ }^{13}$ In the procedure of control of calculations and payments of public revenue up to November 2000, liabilities in a total amount of 2.3 billion kuna were determined, of which 2.2 billion kuna was determined in legal entities (95.96\%), natural entities 74.2 million kuna $(3.26 \%)$ and at financial institutions 17.7 million kuna $(0.78 \%)$.
} 
$(1 / 2) \times 100($ in $\%)$

43.5

42.7

51.1

24.0

Source: FinPol (2000), paper of Financial Police of the Republic of Croatia, No. 33 and 34

FinPol (2001), paper of Financial Police of the Republic of Croatia, No. 35.

In the 1997-1999 period the percentage of collection of public revenue rose to $51.1 \%$ during 1999 , while in 2000 it fell to no more than $24 \%$. The previous research showed that the percentage of the collection of public revenue ranged between 43 and $51 \%$.

We shall also take figures concerning the performance of the FP during the 1998 to 2000 period as one of the indicators of the efficiency of its work.

Table 8a Review of FP performance from 1998 to 2000

\begin{tabular}{|c|c|c|c|c|c|c|c|}
\hline $\begin{array}{l}\text { FP } \\
\text { performance } \\
1998-00\end{array}$ & $\begin{array}{r}\text { Number of } \\
\text { checks } \\
\text { carried out }\end{array}$ & $\begin{array}{r}\text { Number of } \\
\text { misdemeanours } \\
\text { reported }\end{array}$ & $\begin{array}{r}\text { Number of } \\
\text { economic } \\
\text { offences } \\
\text { reported }\end{array}$ & $\begin{array}{r}\text { Criminal } \\
\text { reports } \\
\text { made }\end{array}$ & $\begin{array}{r}\text { Public } \\
\text { revenue } \\
\text { determined in } \\
\text { million kuna }\end{array}$ & $\begin{array}{r}\text { Public } \\
\text { revenue } \\
\text { collected in } \\
\text { million kuna }\end{array}$ & $\begin{array}{r}\text { Number of } \\
\text { premises } \\
\text { closed }\end{array}$ \\
\hline 1 & 2 & 3 & 4 & 5 & 6 & 7 & 8 \\
\hline 1998 & 6,086 & 3,595 & 359 & 187 & $1,098.9$ & 469.5 & 172 \\
\hline 1999 & 5,815 & 3,973 & 570 & 248 & $1,575.5$ & 805.4 & 225 \\
\hline $\begin{array}{l}\text { Index } \\
(99 / 98)\end{array}$ & 96 & 111 & 159 & 133 & 143 & 172 & 131 \\
\hline 2000. & 5,200 & 3,428 & 646 & 333 & $2,407.8$ & 578.3 & 99 \\
\hline $\begin{array}{l}\text { Index } \\
(00 / 99)\end{array}$ & 89 & 86 & 113 & 134 & 153 & 72 & 44 \\
\hline $\begin{array}{l}\text { Index } \\
(00 / 98)\end{array}$ & 85 & 95 & 180 & 178 & 219 & 123 & 58 \\
\hline Total & 17,101 & 10,996 & 1,575 & 768 & $5,082.2$ & $1,853.2$ & 496 \\
\hline
\end{tabular}

Source: FinPol (2000), paper of Financial Police of the Republic of Croatia, No. 33 and 34

FinPol (2001), paper of Financial Police of the Republic of Croatia, No. 35.

During the last years of the work of the FP, the number of checks carried out by this service fell (1999 5,815 , of which 3,117 were in legal entities, 2,434 in natural entities and 264 in financial institutions; in 2000 , there were 5,200, of which there were 2,672 in legal entities, 2,156 in physical entities and 372 in financial institutions), while the amount of public revenue determined rose. This trend and these indicators are in accordance with the previous research from 2000. The improvement on the previous results was preceded by the direction of FP activities to checks on the major economic actors, with, at the same time, an improvement in the quality, planning, preparation and organisation of the inspections.

During 1999 and 2000 the number of misdemeanours reported by the FP fell from 3,961 to 3,428. However, the number of economic offences reported rose from 570 to 646 , and the number of criminal reports rose from 249 to 333 , along with an increase in the number of persons reported and the number of offences for which these persons were reported.

In the work of the FP, an increasing emphasis was placed on major inspections and major legal entities, and to some extent inspections of small taxpayers were neglected.

In this research, unlike in the previous research, we were able to obtain certain, admittedly incomplete, data about the structure of tax revenue collected. 
According to FP data, of totally determined liabilities in 1999 in the amount of 1,575.5 million kuna, corporate income tax amounted to 298.8 million kuna.

And for 2000 , of the liabilities totally determined, 237.9 million kuna was accounted for by corporate income tax, 458.7 million kuna by personal income tax, and 610.1 million kuna by retirement insurance contributions. The liabilities determined on these bases were newly-determined liabilities, and these results are an indicator of the continuous increase in the efficiency of the work performed by the FP, if one takes into consideration the diversity and specificity of the individual species of taxpayer inspected.

Revenue collected in the current year is the result of the compulsory collection of determined public revenue from the previous year and court decisions in the current year, which are related to cases from previous years.

Table 9 Public revenue collected by the FP (in million kuna)

\begin{tabular}{|l|r|r|r|r|r|r|r|r|}
\hline Public revenue collected from: & $\mathbf{1 9 9 7}$ & $\mathbf{\%}$ & $\mathbf{1 9 9 8}$ & $\mathbf{\%}$ & $\mathbf{1 9 9 9}$ & $\mathbf{\%}$ & $\mathbf{2 0 0 0}$ & $\mathbf{\%}$ \\
\hline Current year & 293.7 & 69.5 & 331.7 & 70.6 & 675.7 & 83.9 & - & - \\
\hline Previous years & 129.1 & 30.5 & 137.8 & 29.4 & 129.6 & 16.1 & - & - \\
\hline Total & $\mathbf{4 2 2 . 8}$ & $\mathbf{1 0 0 . 0}$ & $\mathbf{4 6 9 . 5}$ & $\mathbf{1 0 0 . 0}$ & $\mathbf{8 0 5 . 3}$ & $\mathbf{1 0 0 . 0}$ & $\mathbf{5 7 8 . 3}$ & $\mathbf{1 0 0 . 0}$ \\
\hline
\end{tabular}

Source: FinPol (2000), paper of Financial Police of the Republic of Croatia, No. 33 and 34.

FinPol (2001), paper of Financial Police of the Republic of Croatia, No. 35.

Data from the previous research show that about $70 \%$ of compulsorily collected public revenue during 1997 related to court decisions from the current year, and $30 \%$ to court decisions related to tax cases from previous years.

In following years, public revenue related to court decisions and liabilities incurred in the current year increased both absolutely and relatively. Thus public revenue collected for 1999 came to $83.9 \%$ of total revenue collected by the $\mathrm{FP}$, the remaining $16.1 \%$ relating to tax liabilities incurred in previous years. We were not able to make this analysis for 2000 . We can only conclude that the total level of collected public revenue fell a great deal, from 805.3 million kuna in 1999 to 578.3 million kuna in 2000. Data about public revenue collected by the FP for 2001 are not known.

The increase in the level of public revenue in 1999 was very likely the consequence of the greater activities of the FP and the courts because of the budgetary difficulties that came as a result of a fall in budgetary revenue.

After everything shown here, it worth pondering why the FP was abolished when year after year it showed increased degrees of efficiency.

\section{COSTS OF THE CUSTOMS ADMINISTRATION}

In the next part of the paper we shall show the trends in revenue and expenditure (administrative costs) of the Customs Administration from 1997 to 2001. Then we shall make certain recommendations for a reduction in the administrative costs outlined and improvements in the customs system. 
According to Croatian regulations, only the Republic has the right to introduce customs duties, hence revenue from customs duties levied is the revenue of the national Budget. The Republic of Croatia via the bodies of the Customs Administration (CA) carries out the customs clearing procedure. Customs duties are paid on goods that are imported, brought in or received in the post from abroad if so stated in the Customs Tariff ${ }^{14}$. If it is determined that there is a liability to pay customs duty, the CA charges the amount of the customs duty together with excise, value added tax and other import duties (Jelčić, B. et al., 1999).

\section{Administrative costs of the Customs Administration}

In order to be able to calculate the administrative costs of the CA per unit of CA income, we shall first of all provide a picture of the revenue and then of the expenditure of the CA (the administrative costs). In Croatia in 1999, revenue from customs duty (budgetary revenue) made up about $7 \%$ of total tax revenue of consolidated general government (Ministry of Finance, 2001a) ${ }^{15}$. Apart from budgetary sources of financing, the CA also has its own resources. The CA's own resources in 1999 were created mainly via customs fees, then via fines for customs offences, from the sale of goods confiscated for customs offences and from resources brought forward from the CA from previous years (National Auditing Office, 2002). The CA's own revenue is revenue that the CA charges for handling costs when it collects the road charges for foreign vehicles and trailers, and a certain percentage of the actual road charges for foreign road motor vehicles and trailers. Table 10 shows the budgetary and own revenue of the CA from 1997 to 2001.

Table 10 Budgetary and own revenue of the CA (in million kuna)

\begin{tabular}{|l|r|r|r|r|r|r|r|r|r|r|}
\hline & $\mathbf{1 9 9 7}$ & $\mathbf{\%}$ & $\mathbf{1 9 9 8}$ & $\mathbf{\%}$ & $\mathbf{1 9 9 9}$ & $\mathbf{\%}$ & $\mathbf{2 0 0 0}$ & $\mathbf{\%}$ & $\mathbf{2 0 0 1}$ & $\mathbf{\%}$ \\
\hline $\begin{array}{l}\text { Revenue from } \\
\text { customs duty }\end{array}$ & $4,675.5$ & 99.3 & $4,256.3$ & 99.4 & $4,437.3$ & 99.4 & $3,896.5$ & 99.4 & $4,229.4$ & 98.8 \\
\hline Own revenue & 31.5 & 0.7 & 24.5 & 0.57 & 27.3 & 0.6 & 25.3 & 0.6 & 49.1 & 1.2 \\
\hline $\begin{array}{l}\text { Total CA } \\
\text { revenue }\end{array}$ & $\mathbf{4 , 7 0 7 . 0}$ & $\mathbf{1 0 0 . 0}$ & $\mathbf{4 , 2 8 0 . 8}$ & $\mathbf{1 0 0 . 0}$ & $\mathbf{4 , 4 6 4 . 6}$ & $\mathbf{1 0 0 . 0}$ & $\mathbf{3 , 9 2 1 . 7}$ & $\mathbf{1 0 0 . 0}$ & $\mathbf{4 , 2 7 8 . 5}$ & $\mathbf{1 0 0 . 0}$ \\
\hline
\end{tabular}

Source: CA, Ministry of Finance, 2002.

Budgetary revenue from customs duties constitute about 99pc of the revenue of the CA, while the CA's own revenue is relatively small. We should mention that in joining the WTO Croatia agreed to a gradual reduction of tariff protection, and in the future the total amount obtained from customs duty in the budget should gradually reduce.

Like every organisation, the CA has its own costs ${ }^{16}$. Most of the costs of the performance of the CA's affairs are financed from the national Budget, but a part is also financed out of its own revenue. The CA expenditure financed from the budget and those financed from its own resources together make up the administrative costs of the Customs Administration. Data about the administrative costs of the CA in the period from 1997 to 2001 are shown in Table 11.

\footnotetext{
${ }^{14}$ Goods that are only exported or taken out of the Croatian customs area, or are taken across it are not subject to the payment of customs duty, but are subject to a special measure of the organs of the customs service - customs control.

${ }^{15}$ For a comparison, revenue from excise in 1999 came to about $10 \%$ and revenue from corporate income tax to about $5 \%$ of total tax revenue of consolidated general government.

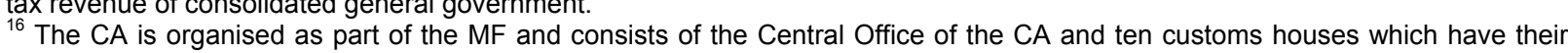
own separate stations.
} 
Table 11 The administrative costs of the CA from 1997 to 2001 (in million kuna)

\begin{tabular}{|l|r|r|r|r|r|r|r|}
\hline & $\mathbf{1 9 9 7}$ & $\mathbf{1 9 9 7}$ & $\mathbf{1 9 9 8}$ & $\mathbf{1 9 9 9}$ & $\mathbf{2 0 0 0}$ & Plan 2001* $^{*}$ & Plan 2001* \\
\cline { 2 - 7 } & & $\boldsymbol{\%}$ & $\mathbf{\%}$ & $\mathbf{\%}$ & $\mathbf{\%}$ & $\mathbf{\%}$ & \\
\hline Financed from the Budget & 205.8 & 85.0 & 90.0 & 92.0 & 97.0 & 85.1 & 246.3 \\
\hline Financed with CA own resources & 35.0 & 15.0 & 10.0 & 8.0 & 3.0 & 14.9 & 42.9 \\
\hline Total CA expenditure (Administrative costs) & $\mathbf{2 4 0 . 8}$ & $\mathbf{1 0 0 . 0}$ & $\mathbf{1 0 0 . 0}$ & $\mathbf{1 0 0 . 0}$ & $\mathbf{1 0 0 . 0}$ & $\mathbf{1 0 0 . 0}$ & $\mathbf{2 8 9 . 2}$ \\
\hline
\end{tabular}

Source: Customs Administration, Ministry of Finance 2002; Decision concerning the proclamation of the national Budget of the Republic of Croatia for 2001, Official Gazette, 130/00.

* In the analysis we shall ignore the amounts from the Budget Plan for 2001, because this is not the execution.

During the years the amount of the administrative costs of the CA financed from budgetary resources has risen. Thus in 2000 the CA financed $97 \%$ of its expenditure from the Budget and only $3 \%$ from its own revenue.

The question arises on what the CA spends its money. What do the administrative costs of customs clearing amount to? Unfortunately, it is not possible to find out the structure of CA expenditure financed from its own revenue, and over the course of the years the classification of CA budgetary expenditures has changed. For this reason in Table 12 we shall give only the structure of the budgetary expenditures of the CA according to the current classification of expenditure, in the period from 1999 to 2001.

Table 12 Structure of CA budgetary expenditure as percentage of total expenditure

\begin{tabular}{|c|c|c|c|}
\hline Structure & 1999 & 2000 & Plan 2001* \\
\hline Staff expenditure & 75.7 & 83.0 & 81.7 \\
\hline $\begin{array}{l}\text { Expenditure for materials, power, utility and other services for } \\
\text { regular use }\end{array}$ & 13.6 & 10.8 & 14.2 \\
\hline Current maintenance expenditure & 3.8 & 0.9 & 1.0 \\
\hline Financial and other external expenditure & 0.1 & 0.1 & 1.3 \\
\hline $\begin{array}{l}\text { Expenditure for the procurement, construction and investment } \\
\text { maintenance of fixed assets (capital expenditure) }\end{array}$ & 6.8 & 5.2 & 1.8 \\
\hline Total expenditure & 100.0 & 100.0 & 100.0 \\
\hline
\end{tabular}

Source: Customs Administration, Ministry of Finance 2002; Decision concerning the proclamation of the national Budget of the Republic of Croatia for 2001, Official Gazette, 130/00.

* In the analysis we shall ignore the amounts from the Budget Plan for 2001, because this is not the execution of the budget.

As with the TA, it is staff expenditure that has a dominant role in the structure of CA budgetary expenditure. On the one hand an upward trend can be noticed, and on the other hand a falling trend in capital expenditure. The previous research (Bajo and Ott, 2000) produced almost the same findings. At the end, according to total staff expenditure and number of employees in the period from 1997 to 2001 we calculated the average expenditures per CA employee.

Table 13 Expenditure per CA employe***

\begin{tabular}{|c|c|c|c|c|c|}
\hline & 1997 & 1998 & 1999 & 2000 & Plan 2001* \\
\hline Staff expenditure ${ }^{\star * *}$ (in million kuna) & 144,376 & 167,661 & 209,180 & 222,883 & 201,289 \\
\hline Number of employees & 2,670 & 2,795 & 2,861 & 2,885 & 2,859 \\
\hline Expenditure per employee & 54,073 & 59,986 & 73,114 & 77,256 & 70,405 \\
\hline
\end{tabular}

Source: Customs Administration, Ministry of Finance 2002; Decision concerning the proclamation of the national Budget of the Republic of Croatia for 2001, Official Gazette, 130/00.

* In the analysis we shall ignore the amounts from the Budget Plan for 2001, because this is not the execution of the budget. 
** Data concerning the number of employees in the CA differ in different sources. We use Ministry of Finance data, which seem to us the most realistic.

*** Gross pay and other wages, employer's contributions and expenses.

From 1997 to 2000 a trend was recorded towards a growth in budgetary expenditure per CA employee. In 2000 for one employee an average 77,000 kuna were paid out per year (gross) or about 6,400 kuna per month. However, since the previous research says that the CA's own resources are mainly used for incentives to employees (training), modernisation of work and so on, it would be logical to include these amounts too into the analysis of the amount of the total expenditure per employee. However, we did not manage to find out the structure of CA expenditure financed from CA own resources, and thus Table 13 gives only the budgetary expenditure per CA employee.

The same problem arises with the structure of CA own resources which, so far, it has been impossible to establish. For this reason it is not entirely clear how much has really been spent per TA and CA employee. Finally, we shall state the most interesting item of information of this analysis, in Table 14, and that is, how much the CA spends in order to collect one kuna of total customs revenue. This indicator will be used as a relative indicator of the efficiency of the work of the CA.

Table 14 Administrative costs of the CA per unit of total CA revenue (customs duties and CA own revenues)

\begin{tabular}{|l|r|r|r|r|r|}
\hline & 1997 & $\mathbf{1 9 9 8}$ & $\mathbf{1 9 9 9}$ & $\mathbf{2 0 0 0}$ & Plan 2001* $^{*}$ \\
\hline Total CA revenue (million kuna) & $4,707.5$ & $4,280.8$ & $4,464.6$ & $3,921.8$ & $4,278.5$ \\
\hline Administrative costs & 240.8 & 253.6 & 304.3 & 276.9 & 289.3 \\
\hline$($ AC/TCAR $) * 100(\%)$ & 5.1 & 5.9 & 6.8 & 7.1 & 6.7 \\
\hline
\end{tabular}

Source: Customs Administration, Ministry of Finance. 2002.

* In the analysis we shall ignore the plan for 2001 , since this is not execution.

To collect one kuna of customs duty, the CA year by year spends an increasing amount of money, spending about 7 lipa in 2000. In the previous research, Ott and Bajo did not have data about the CA's own resources spent, and hence our analysis and theirs are not comparable, although in that report too, from 1997, a trend towards a rise in the administrative costs of the CA can be seen.

It is true that it is hard to say from these data whether our CA is efficient or not, because we could not obtain comparable data from other countries, and even if we had been able to, it is a question to what extent data from various different countries can be compared. What we can say that that any event there should be an attempt to reduce the administrative costs of the CA, which, partially because of WTO entry, have had a tendency to rise, the more so in that it is expected that in the future revenue from customs duty will drop off. In order to be able to arrive at recommendations for reduction of CA costs it is necessary to start at their causes. We shall identify problems within the organisation and the performance of the customs procedure and the customs system as some of the most important causes of the large administrative costs, as well as the problem of the collection of public revenue within the framework of the CA.

For the sake of reducing the costs of customs compliance, the IPF's research about the costs of customs compliance for those who are liable to pay customs duties carried out on a sample of 100 customs duty payers resulted in the knowledge that some of these persons liable to pay customs duties 
considered the customs laws and the customs procedures too complicated and non-transparent and that they changed too frequently. Customs orders are often carried out however a given customs officer wants to interpret them, since they are illogical and/or inconsistent. Further, the procedure for the customs clearing of goods, in particularly for filing documents about plants, animals and market control lasts too long. All this is connected with inappropriately defined legislative regulations, the nonfunctioning of both the $\mathrm{CA}$ and some other governmental institutions, the inefficiency of the work of customs officers and inadequate control of and supervision of their work.

\section{TOTAL ADMINISTRATIVE COSTS OF THE TAX ADMINISTRATION, FINANCIAL POLICE AND CUSTOME ADMINISTRATION}

According to data given so far, we shall endeavour to present the total administrative costs of the collection of public revenue.

Table 15 Total administrative costs (in million kuna)

\begin{tabular}{|l|r|r|r|r|r|r|r|r|r|r|}
\hline & $\mathbf{1 9 9 7}$ & $\mathbf{\%}$ & $\mathbf{1 9 9 8}$ & $\mathbf{\%}$ & $\mathbf{1 9 9 9}$ & $\mathbf{\%}$ & $\mathbf{2 0 0 0}$ & $\mathbf{\%}$ & Plan 2001 & $\%$ \\
\hline TA & 390.8 & 58.0 & 467.6 & 59.0 & 517.9 & 54.9 & 498.3 & 57.7 & 430.7 & 53.9 \\
\hline FP $^{* *}$ & 77.7 & 12.0 & 92.6 & 12.0 & 120.8 & 12.8 & 88.8 & 10.3 & 79.9 & 9.9 \\
\hline CA $^{* *}$ & 205.8 & 30.0 & 228.7 & 29.0 & 304.3 & 32.3 & 276.9 & 32.0 & 289.3 & 36.2 \\
\hline Total & $\mathbf{6 7 4 . 3}$ & $\mathbf{1 0 0 . 0}$ & $\mathbf{7 8 8 . 9}$ & $\mathbf{1 0 0 . 0}$ & $\mathbf{9 4 3 . 0}$ & $\mathbf{1 0 0 . 0}$ & $\mathbf{8 6 4}$ & $\mathbf{1 0 0 . 0}$ & $\mathbf{7 9 9 . 9}$ & $\mathbf{1 0 0 . 0}$ \\
\hline
\end{tabular}

** For the whole of the period under observation, no data are shown for the FP concerning expenditure financed from the department's own resources or for the CA during 1997 and 1998.

In the structure of total administrative expenditure, it is still, as in the previous research, the TA that is most important, with a share of around 57\%, during the 1997 to 2001 period; then comes the CA at $32 \%$, and then the FP with an $11 \%$ share in the total administrative costs. As we can see, the total amount of the administrative costs of all the administrations has reduced from 943 million kuna in 1999 to 799.9 million in 2001.

In the previous research the total costs of the CA and the FP were not stated, because the data about expenditure financed from their own resources could not be obtained. However, during this investigation we did manage to arrive at some information about expenditure of the CA.

But we still do not have any information about expenditure of the FP financed from its own resources.

Table 16 Number of employees in the tax authorities

\begin{tabular}{|l|r|r|r|r|r|r|r|r|r|r|}
\hline Number of employees & $\mathbf{1 9 9 7}$ & $\mathbf{\%}$ & $\mathbf{1 9 9 8}$ & $\mathbf{\%}$ & $\mathbf{1 9 9 9}$ & $\mathbf{\%}$ & $\mathbf{2 0 0 0}$ & $\mathbf{\%}$ & $\mathbf{2 0 0 1}$ & $\mathbf{\%}$ \\
\hline TA & 3,285 & 48.5 & 3,679 & 50.3 & 3,915 & 51.4 & 3,956 & 51.3 & 3,814 & 51.7 \\
\hline FP & 820 & 12.1 & 846 & 11.5 & 837 & 11.0 & 872 & 11.3 & ${ }^{*}$ cca 700 & 9.5 \\
\hline CA & 2,670 & 39.4 & 2,795 & 38.2 & 2,861 & 37.6 & 2,885 & 37.4 & 2,859 & 38.8 \\
\hline Total & $\mathbf{6 , 7 7 5}$ & $\mathbf{1 0 0 . 0}$ & $\mathbf{7 , 3 2 0}$ & $\mathbf{1 0 0 . 0}$ & $\mathbf{7 , 6 1 3}$ & $\mathbf{1 0 0 . 0}$ & $\mathbf{7 , 7 1 3}$ & $\mathbf{1 0 0 . 0}$ & ${ }^{*} \mathbf{7 , 3 7 3}$ & $\mathbf{1 0 0 . 0}$ \\
\hline
\end{tabular}

*This item was taken from Vjesnik, 25 May 2001, since there are no official data about the number of FP employees during 2001.

The total number of employees in the 1997 to 2000 period increased. During 2001, however, we do not have any complete information about FP employees. 
The total number of employees fell in all the three departments, especially in the TA, but about 100 employees during 201 , and in the CA by about 30 . We cannot make any conclusions about the FP since we have not got the appropriate data to go on.

The largest department is still the TA, which between 1997 and 2001 has employed an average staff of 3,700 . Second in line with the CA, in which an average of 2,800 employees work, while the smallest service, until its abolition, was the FP, with about 800 employees.

\section{THE FINANCIAL BENEFITS OF ADMINISTRATIVE COSTS - SOME FUNADAMENTAL INDICATORS.}

If we look at the end at administrative costs as a proportion of total budgetary revenue and GDP, the situation is as follows.

Table 17 Administrative costs as percentage of budgetary revenue and of GDP

\begin{tabular}{|l|r|r|r|r|r|}
\hline & $\mathbf{1 9 9 7}$ & $\mathbf{1 9 9 8}$ & $\mathbf{1 9 9 9}$ & $\mathbf{2 0 0 0}$ & $\mathbf{2 0 0 1}$ \\
\hline Budgetary revenue (in million kuna) & 33,846 & 43,808 & 46,357 & 44,636 & 53,504 \\
\hline GDP in current prices (in million kuna) & 123,812 & 137,604 & 142,700 & 157,511 & 169,800 \\
\hline Total administrative costs (in million kuna) & 674.3 & 788.9 & 943.0 & 863.9 & 799,8 \\
\hline Administrative costs as a percentage of: & 1.99 & 1.80 & 2.03 & 1.94 & 1.49 \\
\hline Budgetary revenue & 0.54 & 0.57 & 0.66 & 0.55 & 0.47 \\
\hline GDP &
\end{tabular}

Source: Monthly statistical review of the Ministry of Finance, 76/02.

Administrative costs as a percentage of total budgetary revenue reduced from $2.0 \%$ in 1999 to $1.49 \%$ during 2001. By comparing the data here with those in the previous period observed, from 1995 to 1998 , we can conclude that the trend has remained the same. But one should be careful when making any conclusions. The fact certainly holds is that the number of employees has reduced over time (Table 11), and also the level of total administrative costs has fallen in absolute terms over the course of time (Table 10).

If we look at administrative costs as proportion of GDP, we shall see that here too there has been a declining trend in the last three years. On average, administrative costs have come to about $0.55 \%$ of GDP over this period, which is almost the same as the level in the previous period of research. But for an analysis of how realistic these figures are and whether they are large or small one should look at the results of research in similar countries obtained by the same methodology.

\section{FUNDAMENTAL PROBLEMS OF THE DEPARTMENTS CHARGED WITH COLLECTING TAX AND CUSTOMS REVENUE}

According to data and reports of the National Auditing Office, the fundamental drawbacks of the CA, TA and FP are related to their internal organisations, expenditure, procurement of fixed assets, and especially with the collection of public revenue within the framework of the CA. The list of assets at the border crossings has partially been created. In the FP list total claims are not covered. 
In the findings of the National Auditing Office and its review of the CA operations for 1999 it is said that there is a problem with the collection of public revenue within the context of the CA. The accumulated amount of uncollected revenue from 1999 and preceding years is greater than the total costs of the whole of the CA for that year. As a reason for the non-collection of public revenue, for natural persons it is stated that the collection of claims sent for compulsory collection to the Payments Clearing Institute and the TA is very uncertain in many cases because those liable to pay are natural persons from whom collection is difficult, and that a large number of claims relate to foreign citizens and citizens of the Republic of Croatia who have moved into other countries to unknown addresses. In most cases, for legal entities, the accounts of debtors are frozen for several years, and in many cases there is no chance of collecting via the seizure of assets. As for claims that do not exceed 10,000 kuna, the CA, because of the high costs, does not carry out execution. The relatively important amount of uncollected claims based on bank guarantees is explained by the fact that individual banks have been in difficulties, for which reason the ability to collect on guarantees accepted has become dubious.

Because of all this the National Auditing Office advocates a systematic monitoring of the state of claims and the prompt undertaking of actions for their collection. Apart from being recorded in operational records, the claims should be shown in the books. It is proposed that at the level of the CA Central Office there should be the organisational linkage of people who would oversee the promptness of procedures undertaken and take care of the quality of guarantees received. At the same time it would be necessary to involve employees from the customs law, misdemeanours and finance sections.

The essential reduction of the administrative costs of the CA and the improvement of the customs system requires from the $\mathrm{CA}$ that it address modernisation, creation of skilled teams, building up greater organisational independence and greater resistance to political pressures, better communications with customs payers, and improved efficiency. The director of the $\mathrm{CA}^{17}$ himself says that the customs service has not fulfilled its task of collecting the revenue of the national Budget and putting down crime and the grey economy. For this reason, in this area, radical changes are need. In the continuation of his text, the director said that these changes have already begun and will be accelerated. However, the success of carrying out these changes depends on our society as a whole, which needs further democratisation, the build up of the rule of law and order, and more transparent, long lasting and predictable public finances, which would make the work of the CA easier.

Analysing the problems within the TA, Ott (1998) says that one of the fundamental problems that the Croatian taxpayer meets is that the tax officials often do not act on the laws, but often according to various rule books, instructions and interpretations which can, but do not necessarily always, correspond with what it says in the actual laws.

For the Tax and Customs administrations to be able to carry out their jobs as effectively as possible, the need has to be stressed for a greater orientation to the payers of the taxes and customs duties, specialisation of customs and tax officers, an increasing degree of independence for both departments, incentives to officials via raises, greater salaries, advanced training, promotions and lack of bias during hiring, bonuses and so on. All this would certainly result in a reduction in the corruptibility of the officers of these departments, which is assumed to exist, but very hard to find out. Further, it is necessary to

\footnotetext{
${ }^{17}$ Interview with the Director of the CA, Anton Uljar, in Carinski vjesnik 11/01.
} 
work on the simplification of the tax and customs regulations, which in many cases are too complicated, on the founding of separate departments for relations with payers of taxes and customs duties, special departments for major taxpayers and payers of customs duties and so on.

Brčić and Janičev $(1998)^{18}$ state that organisational improvements are necessary from the point of view of financial independence, the founding of a network of stations and sections for the monitoring/supervision of major taxpayers, the distribution of human resources and cooperation with the tax administrations of other countries and international organisations. Further, in an analysis of the professionalism of TA officers it is said that it is necessary to set up an optimum ratio of tertiary and secondary educated personnel according to the demands of the given jobs, that in every TA officer the number of officials according to the norms of the jobs and the level of expertise with respect to the demands of the given jobs should be reconsidered, that the speed of transmission of data along the communications channel should be stepped up, and the proportion of people with secondary education only should be reduced in favour of those with tertiary qualifications, especially in the determination of taxes.

All this would have an impact on an increase in the efficiency of these departments and thus on the reduction of the administrative costs of taxation and customs clearing.

\footnotetext{
${ }^{18}$ See Brčić and Jančiev, 1998.
} 


\section{Literature}

Allers Maarten (1994) Administrative and Compliance Costs of Taxation and Public Transfers in the Netherlands, Groningen, Rijksuniversiteit Groningen, 1994, XVI, 261 pp.

Arbutina Hrvoje (1998a) Neka pitanja normativnog uređenja i reforme porezne administracije u Hrvatskoj, Financijska praksa, vol.22 (1-2) pp. 119-141.

Australian Taxation Studies Program (2002) $5^{\text {th }}$ International Conference on Tax Administration Current Issues and Future Developments, Sydney, Australia.

Bird, Richard, M. and Casanegra de Jantscher, Milka (1992) Improving tax administration in developing countries, Washington, International Monetary Fund, 403 pp.,

Brčić, Ružica and Janičev, Zoran (1998), Analiza sadašnje porezne uprave u Republici Hrvatskoj, Financijska praksa 22 (1-2); pp. 85-118.

Carinska uprava MF, 2002. Izvješće o broju zaposlenih, ukupnim godišnijm prihodima CU (koji nisu evidentirani u proračunu, ukupnim godišnijm izdacima CU (iz vlastitih sredstava - koji nisu evidentirani u proračunu).

Državni ured za reviziju, 2002. Izvješće o obavljenim revizijama za 2001. godinu, Ministarstvo financija, Carinska uprava i Financijska policija (online). Zagreb: Državni ured za reviziju. Available from: (http://www.revizija.hr/izvj/4-MFIN.DOC)

Državni zavod za statistiku (2001) Statistički ljetopis Republike Hrvatske.

FinPol (2000), Journal of the Financial Police of the Republic of Croatia, nos. 33 and 34.

FinPol (2001), Journal of the Financial Police of the Republic of Croatia, no. 35

IMF, Fiscal Affairs Department (1995), Guidelines for Fiscal Adjustment, Pamphlet Series, No. 49, Washington, D.C.

Internet site of the Ministry of Finance, Republic of Croatia, www.mfin.hr.

Newspaper clippings, Vjesnik of 25 May 2001.

Jelčić, Božidar, Lončarić-Horvat, Olivera, Šimović, Jure and Arbutina, Hrvoje (1999) Hrvatski fiskalni sustavi (financijsko pravo-posebni dio), Birotehnika CDO. $1^{\text {st }}$ edition, Zagreb.

Kesner-Škreb, M., and Kuliš, D. (2002) Porezni vodič za građane. Zagreb: Institut za javne

financije.

Kesner-Škreb, M. (1999) Ukupni troškovi ubiranja poreza, Financijska praksa, vol. 23 (2) pp. 202-207.

Kraft, Evan (1998) Troškovi ispunjavanja porezne obveze - Tema i u Hrvatskoj? Financijska praksa, vol. 22 (1-2), pp. 235-255.

Madžarević, Sanja (1997) Porezna evazija, Financijska praksa vol 21. (1-2) pp. 241-259.

Madžarević, Sanja (2002) Procjena porezne evazije u Hrvatskoj, Financijska praksa (1) 2002. pp. 117145.

Ministarstvo financija (2000) Izvršenje proračuna za 1999. godinu.

Ministarstvo financija (2001) Godišnje izvješće.

Ministarstvo financija (2001) Izvršenje proračuna za 2000. godinu.

Ministarstvo financija (2001) Plan proračuna za 2001. godinu.

Ministarstvo financija (2002) Mjesečna statistička izvješća 75, 76, 79, 80.

Ministarstvo financija (1995), Pravilnik o unutarnjem redu Ministarstva financija.

Ministarstvo financija $(1995,1996,1997,1998)$, Pravilnik o izmjenama i dopunama pravilnika o unutarnjem redu Ministarstva financija.

Nunberg, Barbara (2000) Ready for Europe - Public Administration Reform and European Union Accession in Central and Eastern Europe, World Bank Technical Paper No. 456. 
Ott, Katarina and Anto Bajo (2000.) Troškovi oporezivanja u tranzicijskim zemljama: iskustvo Hrvatske, Financijska teorija i praksa 24 (2) pp. 169-188.

Porezna uprava Ministarstva financija (1999.) Izdaci PU u odnosu na financijski plan proračuna u razdoblju od 01.01.-31.12.1999.

Porezna uprava Ministarstva financija (2000.) Izdaci PU u odnosu na financijski plan proračuna u razdoblju od 01.01.-31.12.2000.

Porezna uprava Ministarstva financija (2001.) Izdaci PU u odnosu na financijski plan proračuna u razdoblju od 01.01.-31.12.2001.

Sandford, Cedric, Michael Godwin, and Peter Hardwick (1989) Administrative and compliance costs of taxation, Fiscal Publications, XIV, 293 pp.

Tanzi, Vito and Anthony, Pellechio (1995) The reform of tax administration, IMF working paper; WP/95/22, Washington, D.C., International Monetary Fund.

Uljar, A., (2001) Nikad zadovoljni postignutim! Carinski vjesnik, 10 (11) pp. 3 - 4.

Vehorn, Charles L., (1999), Mogućnosti organizacijskog ustroja porezne uprave, Financijska teorija $i$ praksa 23 (4-5), pp. 425-453.

Walpole, Michael and Evans, Chris (2001) Tax Administration in the $21^{\text {st }}$ Century, A Prospect Intelligence Report, Australia.

Odluka o proglašenju državnog proračuna Republike Hrvatske za 2001. godinu, Zagreb: Narodne novine, 130/00. 


\section{INSTITUTE OF PUBLIC FINANCE - OCCASIONAL PAPER SERIES}

No. 1 State Intervention for Growth Promotion in Market Economies

Marina Kesner Škreb, January 1997

No. 2 Estimate of Revenues from the Value Added Tax in the Republic of Croatia

Danijela Kuliš and Žarko Miljenović, October 1997

No. 3 The Unofficial Economy in Croatia: Causes, Size and Consequences

Ivo Bićanić and Katarina Ott, November 1997

No. 4 Price Effects of VAT Introduction in Croatia

Martina Dalić, December 1997

No. 5 Tax Administration Reform in Transition: The Case of Croatia

Katarina Ott, April 1998

No. 6 The Present Sate of the Croatian Public Debt

Zoran Bubaš, December 1998

No. 7 Public Investment in Croatia

Katarina Ott and Anto Bajo, March 1999.

No. 8 Welfare Policy and Social Transfers in Croatia

Predrag Bejaković and Alastair McAuley, July 1999

No. 9 Is Unofficial Economy a Source of Corruption?

Vedran Šošić and Michael Faulend, November 1999

No. 10 Banking Sector Problems: Causes, Resolutions and Consequences

Ljubinko Jankov, March 2000

No. 11 Toward a Long - Term Strategy of Economic Development of Croatia: Where to Begin, What to Do, and How to Do It?

Dubravko Mihaljek, June 2001

No. 12 The Underground Economy in Croatia

Katarina Ott, March 2002

No. 13 An Estimate of the Extent of Tax Evasion in Croatia

Sanja Madžarević Šujster, April 2002

No. 14 Opportunism, Institutions and Moral Costs: The Socio - Cultural Dimension of the Underground Economy in Croatia 1995 - 1999

Aleksandar Štulhofer and Ivan Rimac, April 2002

No. 15 Dollarisation and the Underground Economy: Accidental Partners?

Vedran Šošić and Michael Faulend, April 2002 
No. 16 Decentralization in the Republic of Croatia - A City Budget in the Period from 1996 to 2000

Mihaela Pitarević, March 2003

No. 17 Inequality in Croatia in the Period from 1973 to 1998

Danijeli Nestić, April 2003

No. 18 State Aid to Enterprises in Croatia in 2001

Marina Kesner-Škreb, Ivana Pleše and Mia Mikić, October 2003

No. 19 The Role of Parliament in the Budgetary Process - The Example of the Croatian Parliament (2000-2003)

Vjekoslav Bratić, October 2004

No. 20 Local Government Unit Borrowing in Croatia: Opportunities and Constraints Anto Bajo, October 2004

No. 21 The costs of customs compliance in Croatia in 2001

Mihaela Bronić, November 2004

No. 22 Tax compliance costs of small business in Croatia

Helena Blažić, November 2004

No. 23 The compliance costs of excise duties in Croatia

Danijela Kuliš, November 2004

No. 24 The administrative costs of taxation and customs clearing in Croatia, 1999-2001

Vjekoslav Bratić and Mihaela Bronić, November 2004 